\title{
JOINT TENANCY AND ESTATE TAX AVOIDANCE: A WIDENING LOOPHOLE FOR TRANSFERS IN CONTEMPLATION OF DEATH*
}

Sections 2035 through 2044 of the Internal Revenue Code ${ }^{1}$ prevent the use of inter vivos substitutes for testamentary transfers as a means of avoiding the federal estate tax. ${ }^{2}$ These provisions disregard-for estate tax purposescertain transfers which nominally divest property owners of title ${ }^{3}$ without loss of substantial control.4 Familiar examples of such transfers include grants reserving a life estate to the transferor, transfers in joint tenancy, and

*Sullivan's Estate v. Commissioner, 175 F.2d 657 (9th Cir. 1949), reversing 10 T.C. 961 (1948) ; A. Carl Borner, 25 T.C. No. 70 (Dec. 20, 1955).

1. Int. Rev. CoDe of 1954, $\S \S 2035-44$; Int. Rev. Code of 1939, $\S 811,53$ Stat. 121. The portions of both statutes relevant to this Note are alike; hereinafter current designations are used.

2. See Helvering v. Hallock, 309 U.S. 106, 112 (1940) ; United States v. Wells, 283 U.S. 102, 116-117 (1931) ; 1 PaUl, Federal Estate and Gift Taxatron $\$ 7.05$ (1942) (hereinafter cited as PAUL).

The concept "substitutes for testamentary transfers", while embracing both transiers in contemplation of death and transfers "too much akin to testamentary disnositions" to escape the estate tax, Helvering $\mathrm{v}$. Hallock, supra, is restricted to those transactions described in $\$ \$ 2036-42$ of the Code. See note 4 infra.

Though prevention of tax avoidance is the primary function of these sections, one authority suggests that all inter vivos transfers may one day be subject to the estate tax on the broader ground that they are by definition "substitute testamentary transfers." 1 PavL $\$ 7.05$. On this view, imposition of the tax does not require the presence of some power or interest in the donor at death. Policywise, this would mean a death tax on all property once a generation.

3. Thus, imposition of the tax largely turns on such concepts as "economic contribution" and "control." See text and citations at notes 31 and 32 infra. Distinct tax concepts are similarly employed under the income tax. See, e.g., INT. REv. CODE of 1954, § 61. (formerly $\$ 22$ (a) of the 1939 Code) ; Helvering v. Clifford, 309 U.S. 331, 335-37 (1940) and Burnet v. Wells, 289 U.S. 670,677 (1933) (interpreting $\$ 61$ as cutting across technical concepts of ownership and holding "substantial control" equivalent to legal ownership for income tax purposes). See also INT. Rev. Code of 1954, $\S 677$ (trust income taxed to grantor); id., $\S 704$ (e) (family partnership).

Though tax concepts may be "distinct" from property law, the two are never wholly independent. "For it is state law which creates the economic substance of one's rights, however it may respect traditional [distinctions] ... for nonfiscal purposes." 1 PauL $\$ 1.10$, at 64.

4. Formally, the "substantial control" doctrine does not operate in the estate tax. See Helvering v. Safe Deposit \& Trust Co., 316 U.S. 56 (1942) ; Paul $\$ 4.12$ (Supp. 1946); Note, 64 YALE L.J. 137, 143-45 (1954). Instead, imposition of the tax is contingent on a decedent's retaining at death one of the interests specified by $\$ \S 2036-42$, regardless of his dominion over property by other means. But the concept of "control" is nonetheless basic to the estate tax, since $\$ \$ 2036-42$ uniformly describe transactions whereby decedents have maintained substantial control over property. 
transfers in trust with reserved powers to alter and amend. ${ }^{5}$ To prevent circumvention of estate tax rates, ${ }^{6}$ effort is made to determine a decedent's gross estate by his actual life-time control over property rather than by legal title. Thus, sections 2036 through 2042 specify those indicia of ownership or control which, if retained over previously transferred property until death, may cause the transferor's gross estate to include the entire value of the property and not merely retained interests. ${ }^{7}$ Moreover, section 2035 was intended to strengthen

5. Others include transfers with a general power of appointment reserved, annuity contracts under which the donor receives a life income, and life insurance policies with power in the donor to change beneficiaries.

6. Since a gift tax is presumably paid on inter vivos transfers, INT. REv. CODE OF 1954, $\$ \S 2501-16$, only the higher estate tax rates are protected by $\$ \$ 2035-44$. At present, the gift tax rate is three quarters of the estate tax rate. BITTKER, FEDERAL INCOME ESTATE AND Grft Taxation $\$ 95$ (1955). Compare Int. Rev. CoDe of 1954, \$ 2001 (gift tax) with id., $\$ 2502$ (estate tax). Further impetus for avoiding the estate tax derives from the generous exemptions and separate scale of progression under the gift tax. BITTKER, op. cit. supra at 901 (1955).

7. The relevant portions of these sections are:

"\$ 2036. TRansfers with Retained Life Estate.

(a) GeNerAl Rute.-The ... gross estate shall include ... all property ... to the extent of any interest therein of which the decedent has ... made a transfer ... by trust or otherwise, under which he has retained for his life...

(1) The possession or enjoyment of, or the right to the income from, the property, or

(2) the right ... to designate the persons who shall possess or enjoy the property or the income therefrom....

"S 2037. Transfers Taking Effect At Death.

(a) General Rule.-The . . gross estate shall include . . . all property . . . to the extent of any interest therein of which the decedent has ... made a transfer ... if -

(1) possession or enjoyment of the property can, through ownership of such interest, be obtained only by surviving the decedent, and

(2) the decedent has retained a reversionary interest in the property. . . .

"\$ 2038. Revocable Transfers.

(a) In General.-The ... gross estate shall include ... all property ... [to] the extent of any interest therein of which the decedent has ... made a transfer ... where the enjoyment thereof was subject at ... his death to any change through the exercise of a power ... by the decedent ... to alter, amend, revoke, or terminate, or where any such power is relinquished in contemplation of decendent's death. . . . "\$ 2039. Annuities.

(a) GENERAL. - The gross estate shall include ... an annuity or other payment receivable by any beneficiary by reason of surviving the decedent under any form of contract or agreement ... if, under such contract or agreement, an annuity or other payment was payable to the decedent, or the decedent possessed the right to receive such annuity or payment....

"\$ 2040. JoINT INTERESTS.

The ... gross estate shall include ... all property ... to the extent of the interest therein held as joint tenants ... or as tenants by the entirety by the decedent and spouse ... except such part thereof as may be shown to have originally belonged 
this approach ${ }^{8}$ by imposing like tax consequences on transfers when made "in contemplation of death." In recent years, however, some courts have failed to recognize that these sections are in effect sister provisions, made interdependent to accomplish a common tax purpose. ${ }^{10}$ This failure may enable transferors to relinquish "strings" of control in contemplation of death without incurring the severe tax consequences of control retained at death, thus undermining sections 2036 to 2042 .

to such other person and never to have been received or acquired by the latter from the decedent for less than an adequate and full consideration....

"\$ 2041. Powers of Appointarent

(a) IN General.-The value of the gross estate shall include ... all property ... (1) Powers of appointment created on or before October 21, 1942-To the extent of any property with respect to which a general power of appointment ... is exercised by the decendent ... [and] (2) Powers created after October 21, 1942-To the extent of any property with respect to which the decedent has at the time of his death a general power of appointment. ...

"\$ 2042. Proceeds of Life Insurance

The value of the gross estate shall include ... all property ...

(1) ... to the extent of the amount receivable by the executor as insurance under policies on the life of the decedent.

(2) ... to the extent of the amount receivable by all other beneficiaries as insurance under policies on the life of the decedent with respect to which the decedent possessed at his death any of the incidents of ownership. ..."

8. See, e.g., United States v. Wells, 283 U.S. 102, 116-17 (1931) ; Humphrey's Estate v. Commissioner, 162 F.2d 1 (5th Cir.), cert. denied, 332 U.S. $\$ 17$ (1947). Some such provision is considered essential for a successful estate tax. BirTKER, op. cit. supra note 6 , at 900 (1955) ; 1 PAUL $\S 6.03$. But the complex operation of the statutes, based as they have been on subjective criteria, undercut their effectiveness. 1 id. $\S 6.02$.

9. Int. Rev. Code of 1954, \$ 2035 ; Int. Rev. Code of 1939, § 811.(c), 53 Stat. 121. The 1954 Code added the "three-year" rule, specifying that transfers within three years of death are presumed in contemplation of death. The relevant parts of this section are:

"§ 2035. Transactions In Contearplation of Death.

(a) GENERAL RULE.-The value of the gross estate shall include the value of all property ... to the extent of any interest therein of which the decedent has at any time made a transfer ... by trust or otherwise, in contemplation of his death.

(b) Applicatron of General RulE. - If the decedent within a period of 3 years ending with the date of his death ... transferred an interest in property . . . such transfer ... shall, unless shown to the contrary, be deemed ... in contemplation of death ... ; but no such transfer . . . made before such 3-year period shall be treated as having been made in contemplation of death."

Two other provisions complete the picture. Section 2043 states that where surne consideration has been paid for one of the interests enumerated by prior sections, the grow estate may include only the excess of the fair market value at the time of decedent's death over the consideration received. Section 2044 makes the preceding sections retraactive, except as otherwise specifically provided.

10. Sullivan's Estate v. Commissioner, 175 F.2d 657 (9th Cir. 1949), revirsing 10 T.C. 961 (1948) ; Don Murillo Brockway, 18 T.C. 488 (1952), aff'd on other grounds, 219 F.2d 400 (9th Cir. 1954) ; A. Carl Borner, 25 T.C. No. 70 (Dec. 20, 1955) ; Edward Carnall, 25 T.C. No. 78 (Dec. 28,1955$)$. 
Such failure occurred in Sullivan's Estate v. Commissioner ${ }^{11}$ where sections 2035 and 2040 were not integrated. Sullivan and his wife held as joint tenants securities which had been contributed solely by him. ${ }^{12}$ Shortly before the husband's death, the couple conveyed the securities to their son. This transfer was in contemplation of Sullivan's death, but the Ninth Circuit included only one-half the value of the securities in the husband's gross estate. ${ }^{13}$ The court stated that under local property law the wife owned a one-half interest in the securities, ${ }^{14}$ which was not includible under section 2035 because not transferred in contemplation of her death. In this way property concepts introduced by an isolated treatment of section 2035 determined the gross estate despite the husband's sole contribution and probable control of the joint tenancy. ${ }^{15}$

Recently the tax court in $A$. Carl Borner ${ }^{16}$ extended Sullivan to a tenancy by the entirety. Borner and his wife transferred securities formerly held by them as tenants by the entirety to an irrevocable trust, with income reserved for their joint lives and the life of the survivor. Again, the husband had contributed all the property to the tenancy and the transfer was in contemplation of his death. ${ }^{17}$ Relying on Sullivan, the court included one-half the property in Borner's gross estate and dismissed differences between the tenancies as too insignificant for unlike tax results. ${ }^{18}$

Technically the Borner decision erroneously extended Sullivan because a tenancy by the entirety does not give the wife an interest independent from that of her spouse. In a joint tenancy each tenant owns an undivided interest which he may individually sever. ${ }^{19}$ Doctrinally, the estate is held "by the whole and by the half."20 A tenancy by the entirety, in contrast, is conceptually but

11. 175 F.2d 657 (9th Cir. 1949). Sullivan arose under Int. Rev. Code of 1939, \$§ 811 (c), (e), 53 Star. 121, 122, now $\$ \$ 2035$ and 2040 respectively.

12. This fact is significantly omitted by the court of appeals, though emphasized by the tax court. Frank K. Sullivan, 10 T.C. 961, 973 (1948). For the implications of contribution, see notes $31-34$ and accompanying text.

13. 175 F.2d at $658-59$.

14. The law considered was that of California. See Stark v. Barrett, 15 Cal. 361, 368 (1860) ; People v. Marshall, 8 Cal. 51 (1857); Swartzbaugh v. Sampson, 11 Cal. App. 2d 451, 54 P.2d 73 (1936) ; Oberwise v. Poulons, 124 Cal. App. 247, 12 P.2d 156 (1932).

15. In Sullivan control was easily inferred from such facts as 1) the tenancy property consisted solely of proceeds from the sale of decedent's business; 2) he alone had been investing these proceeds ; 3 ) final disposition of the property was to serve his tax needs. Frank K. Sullivan, 10 T.C. $961,973,962,969$ (1948).

16. 25 T.C. No. 70 (Dec. 20,1955 ).

17. Id. at 2,3 .

18. Id. at 4. See also Edward Carnall, 25 T.C. No. 78 (Dec. 28, 1955), decided the same term. The relevant facts of Carnall and Borner are similar except that in the former the transfer was from decedent and his wife as tenants by the entirety to themselves individually. On the authority of Borner, only one-half the property was included in the husband's gross estate.

19. Burby, Real Property $\$ 189$ (2d ed. 1954); 2 Tiffany, Real Property $\S \S 418$, 425 (3d ed. 1939). Severance converts the estate of two joint tenants into a tenancy in cummon and extinguishes the survivorship right.

20. Id. $\$ 418$, at $196 \&$ n.3. 
one estate held by one person, "by the whole and not by the half," requiring mutual consent for termination. ${ }^{21}$ Thus, Borner's conveyance of the entirety property, though joined by his wife, in theory transferred the whole estate in contemplation of his death. ${ }^{22}$ The full value of the property should therefore have been included in his gross estate. True, the two tenancies are generically similar; tenancy by the entirety is merely a form of joint tenancy modified by the common law fiction that husband and wife are one. ${ }^{23}$ And survivorship is a key feature of both estates. ${ }^{24}$ But the differences have been significant elsewhere in tax and property law. ${ }^{25}$ Above all, since Sullivan turned on technical property law distinctions, the Borner court's disregard for similar refinements seems inconsistent, ${ }^{26}$ though it may reach a practical result. ${ }^{27}$

Of greater significance than this inconsistency, however, is the disjunctive treatment accorded sections 2035 and 2040 in Sullivan itself. The Ninth Circuit contended that since section 2035 does not specify the "quantum" of taxable interest, ${ }^{28}$ Congress intended local property law to determine this

21. Burey, Real Property $\$ 190$, at 328-29 (2d ed. 1954); 2 Anterican LAw of Property $\$ 6.6(\mathrm{~b})$, at 27 (Casner ed. 1952). The estate is held by husband and wife as a unity. Id. at 23 . The most important incident of tenancy by the entirety is that survivorship cannot be defeated by one spouse's conveyance to a stranger. 2 TIFFANY, REAL ProrERTY $§ 430$ (3d ed. 1939).

22. This proposition is nowhere more applicable than in Pennsylvania, the Borners' domicile. There, tenancy by the entirety is "but one estate and, in contemplation of law ... held by one person." Gasner v. Pierce, 286 Pa. 529, 536, 134 At1. 494 (1926) ; Wakefield v. Wakefield, $149 \mathrm{~Pa}$. Super. 9, 11, 25 A.2d 841 (1942). And termination may be effected only by the joint acts of husband and wife, not by either alone. Gallagher Estate, $352 \mathrm{~Pa}$. 476, 43 A.2d 132 (1945). But cf. Zipperlein Estate, 367 Pa. 622, 80 A.2d 817 (1951), declaring that "practicalities" should govern application of the state inheritance tax. This court regarded tenants by the entirety as each having a one-half interest where the contrary result would cause inequitable tax consequences. Borner cites Zippcrlein as furnishing "guidance." 25 T.C. No. 70, at 5.

23. 2 American Law of Property $\S 6.6$ (a), at 23 (Casner ed. 1952); 2 Tiffanx, Real Property \$ 430, at 217 (3d ed. 1939).

24. 2 id. $\$ \$ 419,430$, at $198,218-19$.

25. In the gift tax field, see Commissioner v. Hart, 106 F.2d 269 (3d Cir. 1939); cf. United States v. Jacobs, 306 U.S. 363 (1939) (dissenting opinion).

Creditors' rights may be significantly different as against the two estates. 2 AMERICAN LAW of Property $\$ 6.6$, at 29 (Casner ed. 1952). Though many states have somewhat altered these tenancies by statute, $2 \mathrm{id} . \$ 6.3$, at $11,14 \& \mathrm{n} .12$, they still exist in more than half the jurisdictions, 2 id. $\$ 6.6$, at 31,32 .

26. Compare Sullivan's Estate v. Commissioner, 175 F.2d 657, 658-59 (9th Cir. 1949) ("one joint tenant cannot dispose of anything more than his own interest in the jointly held property. ... [T] [Te half interest conveyed by the wife was not in contemplation of death. She is still living."), with A. Carl Borner, 25 T.C. No. 70, at 4 (Dec. 20, 1955). ("Differences do exist between the two estates but such differences are not sufficient to compel unlike tax results. ...").

27. See note 22 supra and text at notes $38-41$ infra.

28. 175 F.2d at 658. Apparently the term "quantum" is originally Paul's: ". . [L]ocal law always defines the quantum and quality of the interest created, and the cstate tax fastens upon that interest. . . " (Emphasis added.) 1 PAUL $\$ 1.10$, at 72 . By a curious inversion, the Ninth Circuit reasoned from this term to a result which excludes the opera- 
factor. Local property law gives the wife a one-half interest in the joint tenancy which is not within section 2035 because not transferred in contemplation of her death. And section 2040 is inapplicable because the joint tenancy was terminated prior to the husband's death. ${ }^{29}$ In addition, the court noted, the wife might have proportionately reduced the husband's gross estate ${ }^{30}$ by unilaterally severing her interest during his lifetime. But the concept of "ownership" for estate tax purposes is based on economic contribution ${ }^{31}$ and control ${ }^{32}$ rather than the legal abstraction of "title." On this view, the "interest" taxed under section 2040 is measured by the extent of the decedent's contribution to the joint tenancy, ${ }^{33}$ which in both Sullivan and Borner meant the entire amount. ${ }^{34}$ And because transferred in contemplation of death, this "interest" is regarded as if retained by the decedent at death, ${ }^{35}$ and therefore taxable at one hundred per cent under section 2035. Furthermore, unilateral severance by the wife less than three years before her husband's death should not reduce the gross estate because, presumptively, for tax purposes she would

tion of tax concepts upon local law; that is, the contribution principle under $\$ 2040$ was not employed with $\$ 2035$. See notes $32-35$ infra and accompanying text. Thus, in Sullivan local law in effect determined both the interest created and the operation of the estate tax on that interest. The circle is completed by Borncr's bland declaration that local law "cannot control the application of the Federal tax statutes to . . . property rights," while in the same breath expressly approving the Sullivan conclusions.

29. "[A]s to the joint tenancy, the decedent had no interest therein . . . at the time of his death." " 175 F.2d at 660 .

30. For any given joint estate the exact reduction effected by a severance depends on both the size of the interest severed and the amount of the taxable estate. Such a severance may conceivably result in complete avoidance of the estate tax by reducing the taxable estate below the basic $\$ 60,000$ exemption. See InT. REV. Cone of 1954, $\$ 2052$. This follows because the estate tax is a progressive levy. Id., $\$ 2001$. For example, on a taxable estate if less than $\$ 5,000$ the tax is $3 \%$; on a taxable estate of over $\$ 250,000$, but not over $\$ 500,000$, it is $\$ 65,700$ plus $32 \%$ of the excess over $\$ 250,000$; on a taxable estate of over $\$ 10,000,000$, the tax is $\$ 6,0 \$ \$, 200$, plus $77 \%$ of the excess over $\$ 10,000,000$.

31. Narrowly, the "contribution" theory means that the decedent's property and no une clse's must bear the tax: 1 PAUL $\$ 4.04$, at 185 . And the tax is not imposed on transfers for a "full and adequate consideration in money or money's worth." See INT. REv. CODE of 1954, \$\$ 2035-43. Broadly speaking, however, once the objects of taxation are determined, the amount of the tax thereon is reflected by the extent of the decedent's contribution. Section 2040 affords a clear example: once a joint tenancy is found to exist, the tax is moasured according to the economic sources of that interest. U.S. Treas. Reg. 105, $\$ 81.22$. Obviously, more than half the joint estate may thus be taxed. This result was not achieved without considerable litigation. See, c.g., Stuart v. Hassett, 41 F. Supp. 905 (D. Mass. $1941)$ and cases cited.

32. Estate tax "ownership" is based on control insofar as that policy is implemented specifically by $\$ \$ 2036-42$, but no further. See note 4 supra.

33. The operation of $\S 2040$ according to the contribution principle has long been recognized by the Ninth Circuit itself. See, e.g., Richards v. Commissioner, 20 T.C. 904 (1953), aff'd, 221 F.2d Sos (9th Cir. 1955) ; Steen v. United States, 195 F.2d 379 (9th Cir.), cort. dovicd, 344 U.S. $\$ 22$ (1952).

34. See text at notes 12 and 17 supra.

35. See Humphrey's Estate v. Commissioner, 162 F.2d 1 (5th Cir. 1947), cert. denied, 332 U.S. 817 (1947) ; Igleheart v. Commissioner, 77 F.2d 704, 711 (5th Cir. 1935). 
then own nothing to transfer. The wife owns nothing because she did not contribute to the tenancy and from a tax standpoint the opportunity for a valid severence ceased when the "contemplation of death" period began. ${ }^{36}$ Thus, reading sections 2035 and 2040 conjunctively gears tax consequences to the purposes underlying these provisions. ${ }^{\mathbf{3 7}}$

The result in Sullivan-taxation of joint tenancies according to legal titlemay be justified, however, in terms of broader tax objectives. Both the need for section 2040 and its effectiveness in preventing tax evasion are highly doubtful. As between spouses, the marital deduction now in the estate tax law obviates the need for using joint tenancies to diminish one spouse's gross estate. ${ }^{38}$ In other situations, the application of section 2040 can be easily avoided by converting a joint tenancy into a tenancy in common, ${ }^{39}$ in which legal title rather than control or contribution is the measure of a decedent's gross estate. ${ }^{40} \mathrm{With}$ out preventing evasion in any substantial fashion, the statute in effect strikes at transactions in which a joint tenancy may have been created for bona fide non-tax purposes. ${ }^{41}$ Hence this section itself might well be modified to include

36. The tax court perceived this:

"The transfer did not ... make the situation any different from what it would have been if the decedent had died immediately before making the gift to his son. . . Never having contributed any of the joint property or consideration, the surviving tenant [zoife] may not be treated under section 811(e) [\$2040] as the oumer of any interest in the property."

Frank K. Sullivan, 10 T.C. 961,974 (1948). (Emphasis added.) No mention or refutation of this reasoning is found in the Ninth Circuit's opinion.

37. See Commonwealth Trust Co. v. Driscoll, 50 F. Supp. 949 (W.D. Pa.), aff'd per curiam, 137 F.2d 653 (3d Cir. 1943), for a proper integration of $\$ \$ 2035$ and 2040 prior to the property law distinction raised in Sullivan.

38. INT. REv. CoDE of 1954, § 2056.

39. See notes 19 and 20 supra. In a tenancy by the entirety, divorce accomplishes the same result in most states. 2 TrFfany, Real Property $\$ 436$, at 235-36 (3d ed. 1939); Burby, Rfal Property $\S 194$ (2d ed. 1954). But in order to evade the tax, such a conversion to tenancy in common must occur more than three years before the death of a sole economic contributor to the tenancy, because $\$ \$ 2040$ and 2035 apply at death and three years before death, respectively. See text of statutes, notes 7 and 9 supra. Under the 1939 Code, such reduction by inter vivos severance was harder to insure, because a transfer any time before death could be held in contemplation of death. Int. Rev. Code of 1939, \$ 811 (c), 53 Stat. 121.

It may be thought that the natural desire of the contributor to preserve control restrains such a severance. Moreover, survivorship is thereby forfeited. But loss of survivorship can be offset by joint wills, though additional probate expense is incurred; besides, in many instances when severance would occur on this plan, survivorship should be less important than tax factors. As for control, no loss need result from a legal severance, since control is at best only as effective as the harmony among tenants.

40. Tenancies in common are not within the scope of $\$ 2040$. U.S. Treas. Reg. 105, \$ 81.22.

41. Critics regard the joint tenancy provision as the most rigorous under the estate tax. 1 PAUL $\$ 8.09$, at 410 . The most telling objection is that tax avoidance need not enter the picture, since in many states joint tenancy is a popular and convenient form of holding property. Of course, joint estates held for commercial uses are normally exempt from the 
in the gross estate as a general rule only a joint tenant's fractional interest irrespective of his contribution to the tenancy, except where the tenancy clearly appears designed to avoid the estate tax. ${ }^{42}$

Nevertheless, by derogating from section 2035 the reasoning of Sullivan threatens to undermine its other related provisions as well as section 2040. Failure to integrate these provisions leads to improper emphasis on technical property concepts, ${ }^{43}$ which in turn obscures the basic aim of preventing inter vivos diminution of the gross estate without corresponding loss of control.44

estate tax under the consideration proviso. But as to those joint estates formed for bona fide non-tax objectives, $\S 2040$ may be punitive. In any event this section is justified only to the extent it actually prevents tax avoidance. Ibid.; and see note 2 supra.

That a tenancy in common is not reached by the estate tax except as to a decedent's property intercst therein harmonizes with the nonevasion policy of these sections, since tenancy in common, lacking the survivorship feature, is not a "productive vehicle" of estate tax avoidance. 1 PaUr $\$ 8.07$. Since a joint tenancy may so easily be converted to tenancy in common, however, tax distinctions between the two are tenuous. Merely that this power has gone unexercized at death does not make the distinction in kind any stronger, though pragmatically some tax evasion is prevented by imposing the tax on a joint tenancy according to the decedent's contribution. In some respects, even this is punitive, since, reasoning from $\$ 2035$ itself, creation of a joint tenancy more than three years before death raises at least the same presumptions of a bona fide non-tax motive as does any other transfer.

42. For optimum solution of the problem, integration of estate and gift taxes seems necessary. See text at notes 49 and 50 infra. In the interim $\$ 2040$ should be revamped. One way is to tax a joint tenant on his property interest only, except where the tenancy was created within three years before the donor's death. As to these latter estates, decedent should be taxed to the full extent of his contribution, because the transfer clearly seems to be a tax avoidance device.

Such an approach also synchronizes with the gift tax. For those joint estates created Lefore the three-year period, 1) a gift tax would be paid on the donee's portion at creation of the interest, and 2) an estate tax would be paid on the donor's share at his death. (Of necessity, the delayed option under INT. REv. CODE oF 1954, $\$ 2515$ would simultaneously be eliminated.) But those joint estates created within three years of the contributor's death would continue to be taxed as at present; because the property would be regarded as retained by decedent at death, see cases cited note 35 supra, any gift tax previously collected would be credited against the estate tax. The changes suggested would remove the punitive aspects of present $\$ 2040$, and at the same time maintain a policy of thwarting tax avoidance. See note 41 supra.

43. To the extent that the federal tax incorporates or respects subtle distinctions in state property law, it necessarily abandons the ideal of giving "uniform application to a nationwide scheme of taxation." Pauz, Selected Studies in Federal Taxation 5 (2d ser. 1938); if. Fox v. Rothensies, 115 F.2d 42, 44 (3d Cir. 1940). But see note 3 supra.

t4. For example, the Ninth Circuit in Sullizan was only somewhat self-conscious abuut the conflict between its holding and the "nonevasion" policy of $\$ \S 2035$ and 2040 . See $175 \mathrm{~F} .2 \mathrm{~d}$ at 659,660 . It remained for a later court to concede this result expressly, though professing no other way out. See Don Murillo Brockway, 18 T.C. 488,499 (1952), aff'd, 219 F.2d 400 (9th Cir. 1954). After approving Sullivan, the tax court stated: "If this result is contrary to the basic purpose of the estate tax statute and there is a loophole in section 811 (c) [2035], the remedy lies with Congress." In view of the lower court's careful analysis in Sullizan and the precedent set by Commonwealth Trust Co. v. Driscoll, 50 F. Supp. 929 (W.D. Pa.), aff'd per curiam, 137 F.2d 653 (3d Cir. 1943), see note 37 supra, the expansion of this so-called "loophole" is surprising. 
To illustrate, an inter vivos gift of a remainder interest in trust, income for life to the donor, is presently taxed by section 2036 if the income right is retained at death. When death is imminent, the donor may release his life estate to the remainderman. Though this release is a "transfer in contemplation of death," the Sullivan reasoning leads to inclusion in the donor's gross estate of merely the property interest transferred: the worthless life estate. ${ }^{45}$ But this result undercuts section 2036 which should bring into the gross estate the entire corpus of a trust where a life estate has been reserved. ${ }^{46}$ This reasoning similarly applies to the relinquishment in contemplation of death of other interests specified in sections 2036 to $2042 .{ }^{47}$

45. Section 2036 does not govern because the life estate was not retained until death. Therefore, § 2035 applies; but under "local law" the only property interest relinquished in contemplation of death is the life estate, not the trust corpus. The life estate is worthless, assuming the transferor's advanced age.

Administration of $\S 2036$ is in accordance with U.S. Treas. Reg. 105, $\$ 81.18$. Recently, a ruling was issued dealing with the argument proposed above. Rev. Rul. 324, 1956 INT. REv. BuLx. No. 28 , at 43 . This opinion correctly holds that relinquishment of a life estate in contemplation of death renders the entire property includible in the gross estate under $\$ 2035$, as if retained at death under $\$ 2036$. Nor can the tax be avoided by payment of a consideration equal to merely the value of the interest relinquished. Two cases construing local statutes similar to the federal estate tax are cited: In re Thurston's Estate, $36 \mathrm{Cal}$. 2d 207, 223 P.2d 12 (1950) ; Heller v. District of Columbia, 198 F.2d 983 (D.C. Cir. 1952). Cf. Allen v. Trust Co., 326 U.S. 630, 635 (1946). Though perhaps prompted by the Sullivan line of cases, the ruling does not mention them. The impact on the courts of this ruling is unpredictable. If accepted, the anomoly would exist of two distinct interpretations of $\$ 2035$, each depending on which related provision was involved in a given case.

46. See, e.g., Myron Selznick, 15 T.C. 716 (1950), aff'd, 195 F.2d 735 (9th Cir. 1952) ; United States v. Stark, 32 F.2d 453 (6th Cir. 1924) ; Carolyn Peck Boardman, 20 T.C. 871 (1953).

47. The argument is particularly applicable to $\$ \S 2037,2039$ and 2042 . Under $\$ 2037$, for example, where decedent had retained certain powers over a trust, he was declared to possess a taxable reversion and the corpus of the trust was included in his gross estate. See Costin v. Cripes, 235 F.2d 162 (7th Cir. 1956). If similarly situated holders of such reversionary interests now attempt to divest their interests in contemplation of death, following Sullivan they may plausibly assert that the only property interest relinquished under $\S 2035$ is the reversion, not the trust corpus. The Sullivan rationale may similarly extend to annuity contracts under $\S 2039$. Ordinarily, by this section an annuity payable to a decedent-father for life, then to a surviving son, is taxable to the father if he has paid the purchase price. Were the father to release the income right in contemplation of death, applying Sullivan, only the balance of the income for decedent's life would be taxed by $\$$ 2035. Finally, the argument extends to "incidents" of insurance ownership, normally taxed according to $\S 2042$. If, say, a power to change beneficiaries were relinquished in contemplation of death, Sullivan would include only the value of the power in the transferor's gross estate. This would effect significant tax savings if applied to middle age transferors. But cf. U.S. Treas. Reg. 105, § 81.25; 1 PAuL $\$ 10.4$ (1946 Supp.).

Sections 2038 and 2041 should not be susceptible to the Sullizan theory. The former provision specifically declares that release of a power to alter or amend in contemplation of death brings a trust corpus into the gross estate, thus avoiding any conflict with $\S 2035$. That this specification occurs here but not in other sections is inexplicable except by the piecemeal fashion these sections were put together. Furthermore, no tax savings would seem to accrue from extending Sullizan to $\S 2041$. This follows if a general power of 
The distortion of tax concepts by technical property law doctrines shows a need for general reform of the gift and estate tax structure. The existing rate differential between the gift and estate taxes invites attack from a property basis which can yield substantial tax savings. ${ }^{48}$ Hence, critics urge integration of the two taxes along a single graduated rate scale. ${ }^{49}$ Such an approach would eliminate the tax advantages which now follow inter vivos diminution of the gross estate; likewise, elaborate doctrine for preserving the gross estate intact would become unnecessary. ${ }^{50}$ Proposals for integration, however, have long been apathetically received by Congress, and there are no current indications of a changed attitude. ${ }^{51}$ The courts are thus obliged to sustain the present tax structure. Accordingly, the Sullivan-Borner doctrine should be restricted to joint estates in the event similar arguments are raised under related provisions.

appointment is regarded as the equivalent of total ownership; on the other hand, if the power were to be valuated by decedent's life expectancy, the tax is practically avoided. See note 45 supra. Of these alternatives, the former is preferable since a general power of appointment confers the possibility of total ownership of the property until death: thus a sale made under the power immediately before death would pass the full consideration to heirs or legatees through the estate.

48. See Helvering v. Hallock, 309 U.S. 106, 118 (1940) (dissenting opinion) ; 1 PauL $\$ 1.12$, at 89 ; Advisory Comimitee to the Treasury Departurent, Federal Estate and Gift Taxation: A Proposal for Integration and for Correlation with the Income TAx 11-12 (1947).

49. Id. at 14-17; 1 Paul $\$ 1.12$, at \&8; Bittker, Federal Income Estate and Gift Taxation 901-02 (1955); Warren, Correlation of Gift and Estate Taxes, 55 HaRv. L. REV. 1 (1941).

50. See especially, Proposal for Integration and for Correlatton with the InCONE TAX, supra note 48 .

51. Thus, the 1954 Code left the gift and estate tax provisions largely unreformed, despite a multitude of proposals. This may be the result of fundamental disagreement over the role of the estate tax in a democratic society. See BITrKer, op. cit. supra note 49 , at $899-904$ (1955). 